\title{
Snakes from the Atlantic Rainforest area of Serra do Mendanha, in Rio de Janeiro state, southeastern Brazil: a first approximation to the taxocenosis composition
}

\author{
Pontes, JAL. *, Figueiredo, JP., Pontes, RC. and Rocha, CFD. \\ Departamento de Ecologia, Instituto de Biologia Roberto Alcantara Gomes, \\ Universidade do Estado do Rio de Janeiro - UERJ, \\ Rua São Francisco Xavier 524, Maracanã, CEP 20550-011, Rio de Janeiro, RJ, Brazil \\ *e-mail: pontesjal@hotmail.com \\ Received August 23, 2006 - Accepted May 11, 2007 - Distributed August 31, 2008 \\ (With 3 figures)
}

\begin{abstract}
We studied the species composition of the snake community of Serra do Mendanha, in Rio de Janeiro state, Southeastern Brazil, with an effort of 800 hours/man in different habitats, including undisturbed forest, secondary forest, areas under regeneration, and banana plantation. We sampled snakes monthly in the area using a combination of methods including intensive visual searching and pitfall traps with drift-fences. We found a total of 191 individuals of 27 snake species, belonging to four families: Boidae, Colubridae, Elapidae and Viperidae. In terms of species richness, the most speciose snake family in the area was Colubridae $(85.2 \% ; \mathrm{n}=23)$, followed by Viperidae $(7.4 \% ; \mathrm{n}=2)$, Boidae $(3.7 \%$; $\mathrm{n}=1)$ and Elapidae $(3.7 \% ; \mathrm{n}=1)$ (Table 1). Quantitatively, the family Colubridae represented $81.7 \%(\mathrm{n}=156)$ of the total of individuals captured throughout the study, followed by Elapidae ( $13.1 \%$ of the individuals; $\mathrm{n}=25$ ), Viperidae $(4.7 \% ; \mathrm{n}=9)$ and Boidae $(0.5 \% ; \mathrm{n}=1)$. The data obtained in the study allowed a first approximation of the richness and composition of the snake fauna from Serra do Mendanha, including the records obtained during fieldwork in the present study and those of specimens deposited in Institutional Collections and detailed field data for each voucher specimen. All records are novel data for the area.
\end{abstract}

Keywords: Snake community, Snake richness, Serra do Mendanha, Atlantic rainforest.

\section{Serpentes da Serra do Mendanha, estado do Rio de Janeiro, sudeste do Brasil: uma primeira aproximação da composição da taxocenose}

\section{Resumo}

Estudamos a composição da comunidade de serpentes da Serra do Mendanha, Estado do Rio de Janeiro, com um esforço de 800 horas/homem nos diferentes hábitats da região incluindo mata pouco perturbada, mata secundária e áreas de cultivo de bananeiras. Para amostrar as serpentes, utilizamos os métodos de procura visual e armadilhas de queda com cercas-guia. Encontramos um total de 191 indivíduos de 27 espécies de serpentes, distribuídas em quatro famílias: Boidae, Colubridae, Elapidae e Viperidae. Em termos de riqueza de espécies, a família com maior número de espécies foi a Colubridae $(85,2 \% ; n=23)$, seguida pela Viperidae $(7,4 \% ; n=2)$, Boidae $(3,7 \% ; n=1)$ e Elapidae $(3,7 \% ; n=1)$ (Tabela 1). Quantitativamente, a família Colubridae representou $81,7 \%(n=156)$ do total de indivíduos capturados durante o estudo; Elapidae (13,1\% dos indivíduos; $n=25)$; Viperidae $(4,7 \% ; n=9)$; e Boidae $(0,5 \% ; n=1)$. Os dados obtidos no presente estudo permitiram uma primeira aproximação da riqueza e composição da fauna de serpentes da Serra do Mendanha, incluindo os registros obtidos durante o trabalho de campo neste estudo, dos espécimes depositados em coleções institucionais e dos dados de campo de cada espécime-testemunho. Todos os registros obtidos são inéditos para a região.

Palavras-chave: comunidade de serpentes, riqueza de serpentes, Serra do Mendanha, Mata Atlântica.

\section{Introduction}

The Atlantic Forest of Serra do Mendanha, which is included in the municipalities of Rio de Janeiro, Mesquita and Nova Iguaçu, in Rio de Janeiro state, Brazil (Figure 1), is approximately 8,500 ha in area, and is one of the world's largest forest remnants located within the limits of a large city (Pontes, 2005; Prefeitura da Cidade do Rio de Janeiro, 2000; Rocha et al. 2003; SEMADS, 2001). This remnant is of considerable con- 

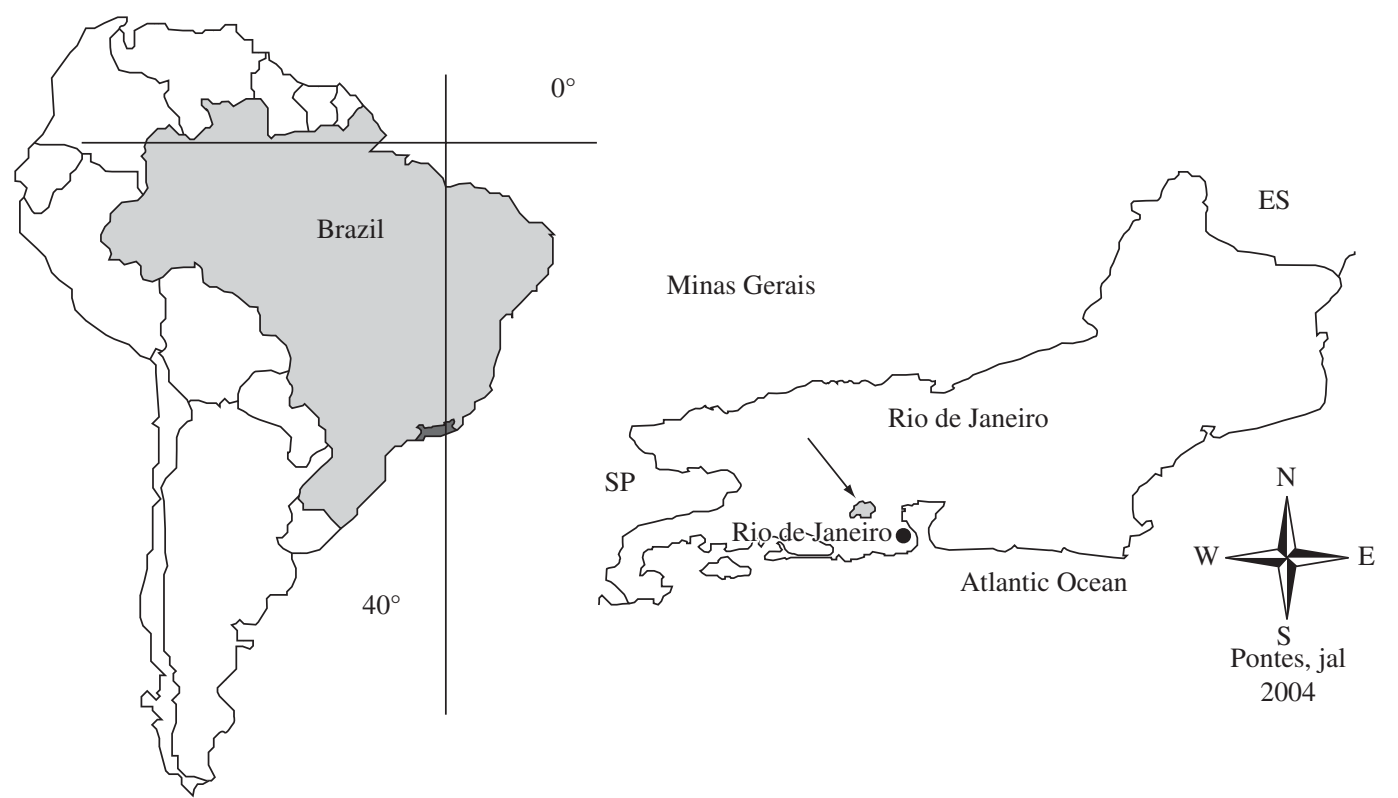

Figure 1. Location of the study area of Serra do Mendanha in Rio de Janeiro state, southeastern Brazil.

servation value not only due to the richness of the flora and fauna this forest contains but also because it is one of the main forest remnants protecting the Guanabara Bay hydrographic basin, which is the main source of water for most municipalities surrounding the Guanabara Bay, including the metropolis of Rio de Janeiro (Pontes, 2005; Rocha et al. 2003; SEMADS, 2001). Despite the relevance of this forest remnant, the knowledge on most of its fauna and flora is still lacking. There is no previous information regarding the snake fauna inhabiting the area. During a project on the snake fauna in the Serra do Mendanha, carried out during 48 months, we monthly sampled snakes in the area which allowed a first approximation of the richness and composition of the snake fauna of the region. Here we present the snake species found, including a first checklist of the species for the Serra do Mendanha Atlantic and provide detailed field data for voucher specimens sampled. All records are novel data for the area.

\section{Material and Methods}

The study was carried out in the Atlantic Rainforest area of Serra do Mendanha, $\left(22^{\circ} 48^{\prime} ; 22^{\circ} 51^{\prime} \mathrm{S}\right.$ and $43^{\circ} 31^{\prime} ; 43^{\circ} 28^{\prime} \mathrm{W}$ ) (Figure 1), located in Rio de Janeiro state, Southeastern Brazil. The region is included in the Atlantic Rainforest Biome and presently is covered with forests with relatively low level of anthropic disturbances and secondary forests with different levels of regeneration. The climate of the area is wet and hot with a relatively dry winter and rainy summer (Aw). The mean annual temperature in the area varies from 18 to $24^{\circ} \mathrm{C}$ and mean annual rainfall averages $1200-2000 \mathrm{~mm}$, with most rain falling from November to March (CLINO, 1996).
We sampled snakes monthly in the Serra do Mendanha from April 2002 to March 2006, totaling around 800 hours/man of study. For the snake species inventory we used a combination of methods including intensive visual searching and pitfall traps with driftfences (Heyer et al. 1994; Cechin and Martins, 2000). Sampling was made at three major habitats in the Serra do Mendanha: undisturbed forest, secondary forest and a disturbed area of the forest (mostly dominated by banana plantations). In each of these three habitats we carried out a similar sampling effort. Intensive visual searching were performed monthly during different times of day and night along four linear transects of $500 \mathrm{~m}$ extension in each of the three habitats, totaling $6 \mathrm{~km}$ of extension for the whole area of Serra do Mendanha each month. In addition, at each habitat we established three systems of pitfall traps. Each pitfall system was composed of a set of four 100 liter gallons disposed along a line in which one gallon was set 10 meters from the next. At each habitat 12 gallons were set, totaling 36 gallons for the whole area. The gallons of each pitfall system were interconnected with drift fences, totaling $50 \mathrm{~m}$ extension of drift fences for each system and a total $450 \mathrm{~m}$ of extension for the whole area. The systems remained open during 24 hours from December 2002 to May 2004. Each pitfall trap was checked every two days throughout the month. For each captured snake, its body length (total length $=$ TTL, and snout-vent length $=$ SVL using measuring tapes to the nearest $1 \mathrm{~mm}$ and Vernier $^{\circledR}$ calipers to the nearest $0.2 \mathrm{~mm}$ ) and mass (to the nearest $\mathrm{g}$ using a Pesola ${ }^{\circledR}$ dinamometer) were taken. The sex of each individual was recorded whenever possible. The altitude (in $\mathrm{m}$ a.s.l.) and the microhabitat used by each snake at the time they were first 
sighted were also registered. Photographs were taken of all captured specimens. Voucher specimens were deposited at the Museu Nacional, Rio de Janeiro (MNRJ). In addition, we supplemented our data with existing specimens from the Serra do Mendanha deposited in the snake collections of the Instituto Vital Brazil (IVB) in Niterói, Rio de Janeiro, the Museu Nacional, Rio de Janeiro (MNRJ) and the Instituto Butantan (IB) in São Paulo. Snakes were identified with the aid of published keys (Campbell and Lamar 2004; Dixon et al. 1993; Hoge and Romano-Hoge, 1978/79; Peters and Orejas-Miranda, 1970; Vanzolini et al. 1980) and a guide for identification of snakes (Marques et al. 2001), and their identities were posteriorly verified by Ronaldo Fernandes (Curator, Herpetology Section, Vertebrate Department Museu Nacional, Rio de Janeiro) and by Daniel S. Fernandes (Herpetology Section, Vertebrate Department Museu Nacional, Rio de Janeiro).

\section{Results and Discussion}

During the study we captured a total of 191 individuals of 24 different snake species through visual researching (Figure 2), belonging to four families: Boidae, Colubridae, Elapidae and Viperidae (Table 1). However, the pitfall traps did not propitiate any capture during this study. In terms of species richness, the most speciose snake family in the area was Colubridae (85.2\%; $\mathrm{n}=23)$, followed by Viperidae $(7.4 \% ; \mathrm{n}=2)$, Boidae $(3.7 \% ; \mathrm{n}=1)$ and Elapidae $(3.7 \% ; \mathrm{n}=1)$ (Table 1$)$. Quantitatively, the family Colubridae represented $81.7 \%$ $(n=156)$ of the total of individuals captured during the study, followed by Elapidae (13.1\% of the individuals; $\mathrm{n}=25)$, Viperidae $(4.7 \% ; \mathrm{n}=9)$ and Boidae $(0.5 \%$; $\mathrm{n}=1$ ) (Figure 3). Additionally, we found three individuals of three snake species deposited in the Institutional Collection of the Instituto Vital Brazil (Erythrolamprus aesculapii, Leptodeira annulata e Siphlophis compressus) which were not sampled during our study in the area, which supplement our data and add three species to the present checklist of the Serra do Mendanha. In the herpetological collection of the Museu Nacional, Rio

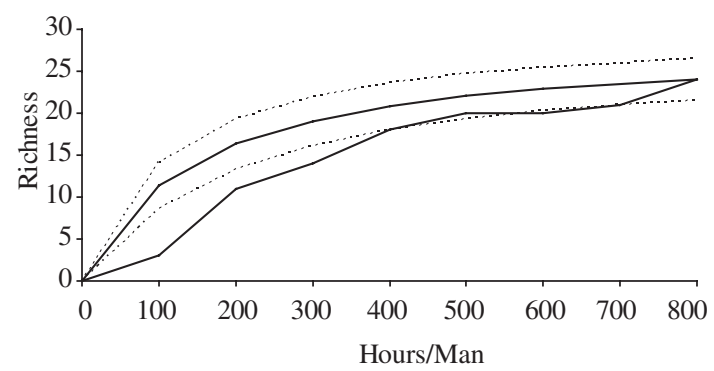

Figure 2. Rarefaction curve (black line) and collector curve (gray line) with $\mathrm{CI}=95 \%$ (traced lines) (EstimateS Program and Mao Tao Indices). Serra do Mendanha in Rio de Janeiro State, Southeastern Brazil. de Janeiro we found seven specimens belonging to five species (Liophis miliaris, L. poecilogyrus, Oxyrhopus petola, Spilotes pullatus and Bothrops jararaca) but all of them were recorded during this study. We did not find snake specimens from the Serra do Mendanha deposited in the herpetological collection of the Instituto Butantan. Voucher specimen of the species recorded in the area are listed in Appendix 1, including information on precise location (coordinates), altitude in the forest, habitat, microhabitat, height above ground, sex, size (in $\mathrm{cm}$ ) and weight (in $g$ ).

The dominance of the family Colubridae found in the present study is compatible to findings in other studies on Brazilian snake assemblages in different Biomes such as the Pantanal (Strüssmann, 1992), the Amazonian forest (Martins and Oliveira, 1998), the Atlantic Forest (Di-Bernardo, 1998; Freire, 2001; Marques, 1998; Rocha, 1998; Rocha et al., 2000; Rocha and Van Sluys, 2006) and in the Cerrado (Sawaya, 2003). This suggests a conservative pattern in the dominance of Colubridae among snake assemblages, independent of the Biome. This trend may result from the fact that Colubridae is the largest and most structurally diverse snake group (Zug et al., 2001).

Considering only the snakes recorded by us in the field, the most abundant species in the snake assemblage of the Serra do Mendanha was Liophis miliaris $(\mathrm{n}=32)$, followed by Micrurus corallinus $(\mathrm{n}=25)$ and Chironius fuscus $(\mathrm{n}=24)$ which together represent around $40 \%$ of the total number of recorded snakes. The least abundant snakes were Elapomorphus quinquelineatus, Pseustes sulphureus and Tropidodryas serra (one individual each species). Chironius fuscus, Liophis miliaris and Micrurus corallinus are, in general, species relatively common in Atlantic Forest areas and have usually been found with considerable frequency in studies realized in other Atlantic forest areas in the states of Rio de Janeiro (Rocha et al. 2000; Rocha and Van Sluys, 2006), São Paulo (Marques, 1998; Marques and Sazima, 2004; Sazima and Haddad, 1992), and Espírito Santo (Rocha, 1998), although the abundance of them differed somewhat from other areas. The variation in the species abundance among snake assemblages probably reflects differences in the local environment and historical features of each region (Di-Bernardo, 1998; Freire, 2001; Marques, 1998). The reduced frequencies of records of some species such as E. quinquelineatus, $T$. serra and $U$. ricardinii in the present study suggests that probably they are comparatively low in abundance in the Serra do Mendanha forest, or it may be due to their secretive or cryptic behavior, or both. The capture of the snake Uromacerina ricardinii represents the first record of this species for the Metropolitan Region of Rio de Janeiro state.

The markedly low abundance of $B$. constrictor (only one individual was found and associated to the anthropic area) could be due to the preference of the species to relatively open areas, which results in usually being found also in low abundance in some forested areas of Atlantic 
Pontes, JAL. et al.

Table 1. Checklist of Snake species from the Atlantic Rainforest area of Serra do Mendanha, in Rio de Janeiro State, Southeastern Brazil. 1) Instituto Vital Brazil, Niterói; 2) Museu Nacional, Rio de Janeiro; and 3) Instituto Butantan, São Paulo.

\begin{tabular}{|c|c|c|}
\hline Snake family/species & $\begin{array}{l}\text { Recorded } \\
\text { in the field }\end{array}$ & $\begin{array}{c}\text { Species housed in } \\
\text { Institutional collections }\end{array}$ \\
\hline \multicolumn{3}{|l|}{ BOIDAE } \\
\hline Boa constricitor Linnaeus, 1758 & $\mathrm{x}$ & - \\
\hline \multicolumn{3}{|l|}{ COLUBRIDAE } \\
\hline Chironius bicarinatus (Wied, 1820) & $\mathrm{x}$ & - \\
\hline Chironius exoletus (Linnaeus, 1758) & $\mathrm{x}$ & - \\
\hline Chironius fuscus (Linnaeus, 1758) & $\mathrm{x}$ & - \\
\hline Chironius laevicollis (Wied, 1824) & $\mathrm{x}$ & - \\
\hline Chironius multiventris Smith e Walker, 1943 & $\mathrm{x}$ & - \\
\hline Echinanthera affinis (Günther, 1858) & $\mathrm{x}$ & - \\
\hline Echinanthera cephalostriata Di Bernardo, 1996 & $\mathrm{x}$ & - \\
\hline Elapomorphus quinquelineatus (Raddi, 1820) & $\mathrm{x}$ & - \\
\hline Erythrolamprus aesculapii (Linnaeus, 1766) & & 1 \\
\hline Helicops carinicaudus (Wied, 1825) & $\mathrm{x}$ & - \\
\hline Leptodeira annulata (Linnaeus, 1758)* & & 1 \\
\hline Leptophis ahaetulla (Linnaeus, 1758) & $\mathrm{x}$ & - \\
\hline Liophis miliaris (Linnaeus, 1758) & $\mathrm{x}$ & 2 \\
\hline Liophis poecilogyrus (Wied, 1835) & $\mathrm{x}$ & 2 \\
\hline Oxyrhopus petola (Linnaeus, 1758) & $\mathrm{x}$ & 1,2 \\
\hline Philodryas olfersii (Lichtenstein, 1823) & $\mathrm{x}$ & - \\
\hline Pseustes sulphureus (Wied, 1825) & $\mathrm{x}$ & 1 \\
\hline Siphlophis compressus (Daudin, 1803) & & 1 \\
\hline Spilotes pullatus (Linnaeus, 1758) & $\mathrm{x}$ & 2 \\
\hline Thamnodynastes hypoconia (Cope, 1860) & $\mathrm{x}$ & - \\
\hline Tropidodryas serra (Schelegel,1837) & $\mathrm{x}$ & - \\
\hline Uromacerina ricardinii (Peracca, 1897) & $\mathrm{x}$ & - \\
\hline Xenodon neuwiedii Günther, 1863 & $\mathrm{x}$ & - \\
\hline \multicolumn{3}{|l|}{ ELAPIDAE } \\
\hline Micrurus corallinus (Merrem, 1820) & $\mathrm{x}$ & 1 \\
\hline \multicolumn{3}{|l|}{ VIPERIDAE } \\
\hline Bothrops jararaca (Wied, 1824) & $\mathrm{x}$ & 1,2 \\
\hline Bothrops jararacussu Lacerda, 1884 & $\mathrm{x}$ & \\
\hline Total number of species $=27$ & 24 & $5(2)$ \\
\hline
\end{tabular}

*specimen recorded in the surrounding area of Serra do Mendanha.

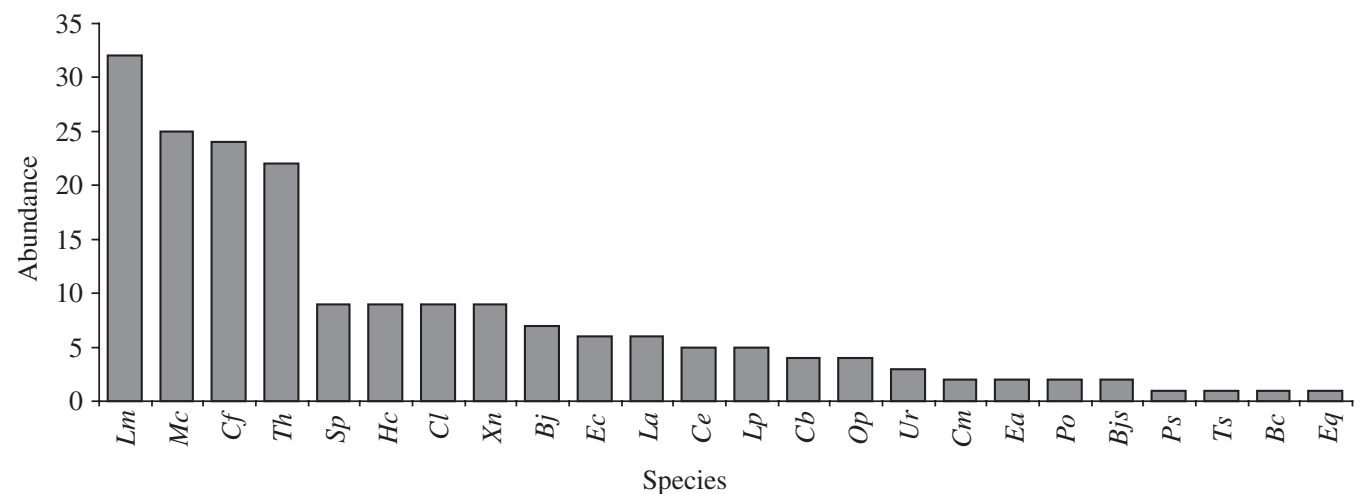

Figure 3. Distribution of abundance for snake species sampled with visual searching ( 800 hours/man), in Serra do Mendanha, Rio de Janeiro State, Southeastern Brazil ( $L m=$ Liophis miliaris, Mc = Micrurus corallinus, $C f=$ Chironius fuscus, $T h=$ Thamnodynastes hypoconia, $\mathrm{Sp}=$ Spilotes pullatus, $\mathrm{Hc}=$ Helicops carinicaudus, $\mathrm{Cl}=\mathrm{C}$. laevicollis, $\mathrm{Xn}=\mathrm{Xenodon}$ neuwiedii, Bj = Bothrops jararaca, Ec $=$ Echinanthera cephalostriata, La $=$ Leptophis ahaetulla, $C e=C$. exoletus, $L p=$ Liophis poecilogyrus, $C b=C$. bicarinatus, $O p=$ Oxyhropus petola, $U r=$ Uromacerina ricardinii, $C m=C$. multiventris, Ea $=E$. affinis, $P o=$ Philodryas olfersii, Bjs $=$ B. jararacussu, $P s=$ Pseustes sulphureus, $T s=$ Tropidodryas serra, $B c=$ Boa constrictor, $E q=$ Elapomorphus quinquelineatus). 
Forest (Rocha, 1998; Rocha et al., 2000) or absent in others (Freire, 2001; Marques, 1998; Rocha and Van Sluys, 2006).

Eleven of the snake species found in Serra do Mendanha (41\%) are endemic to the Atlantic Rainforest Biome (B. jararaca, B. jararacussu, C. bicarinatus, C. laevicollis, C. multiventris, E. affinis, E. cephalostriata, E. quinquelineatus, H.carinicaudus, M. corallinus, T. serra), representing about $18.6 \%$ of the endemic snake species of this Biome. This indicates a considerable value of the conservation of the Serra do Mendanha forest also for snake species.

Acknowledgements - We thank the Secretaria Municipal de Meio Ambiente do Rio de Janeiro for the permits to work at the Parque Natural Municipal da Serra do Mendanha and the Programa de Pós-graduação em Biologia of the Universidade do Estado do Rio de Janeiro - UERJ and the Instituto Biomas for their support. We are also grateful to the park's technicians who assisted us in the field work on several occasions and helped with the installation of the pitfall traps. Davor Vrcibradic kindly reviewed the manuscript. Ronaldo Fernandes and D. S. Fernandes, both of the Departamento de Vertebrados, Museu Nacional, Rio de Janeiro, verified the identity of the specimens. Otavio Marques kindly facilitated access (provided information) to information on snakes deposited in the collection of the Instituto Butantan. The Conselho Nacional do Desenvolvimento Científico e Tecnológico - CNPq, provided grants (Nos. 307653/2003-0 and 477981/2003-8) to CFDR." por "C.F.D.Rocha was granted by the Conselho Nacional de Desenvolvimento Científico e Tecnológico - CNPq (Processes No. 307653/2003-0 and 477715/2006-0) and by the Fundação de Amparo à Pesquisa do Estado do Rio de Janeiro (FAPERJ) through the "Programa Cientistas do Nosso Estado" (Process E-26/100.471.2007).

\section{References}

CAMPBELL, JA. and LAMAR, WW., 2004. The venomous reptiles of the western hemisphere. New York: Cornell University Press. vol. I., 476 p.

CECHIN, SZ. and MARTINS, M., 2000. Eficiência de armadilhas de queda (pitfall traps) em amostragens de anfíbios e répteis no Brasil. Rev. Bras. Zool., vol. 17, no. 3, p. 729-740.

CLINO, 1996. Climatological Normals (CLINO) for the period 1961-1990. Geneva, Switzerland: World Meteorological Organization. p. 768.

DI-BERNARDO, M., 1998. História natural de uma comunidade de serpentes da borda oriental do Planalto das Araucárias, Rio Grande do Sul, Brasil. Rio Claro: Instituto de Biociências, Universidade Estadual de Paulista. 123 p. [Tese de Doutorado em Ciências Biológicas].

DIXON, JR., WIEST Jr., JA. and CEI, JM., 1993. Revision of the neotropical snakes genus Chironius Fitzinger (Serpentes, Colubridae). Torino: Museu Regionale di Scienze Naturali. p. 1-268. [Monographie 13].

FREIRE, EMX., 2001. Composição, taxonomia, diversidade e considerações zoogeográficas sobre a fauna de lagartos $e$ serpentes de remanescentes da Mata Atlântica do Estado de Alagoas, Brasil. Rio de Janeiro: Museu Nacional; Universidade
Federal do Rio de Janeiro. 144 p. [Tese de Doutorado em Ciências Biológicas].

HEYER, WR., DONNELY, MA., ROY, WM., HAYEK, LC. and FOSTER, MS., 1994. Measuring and monitoring biological diversity. Standard methods for amphibians. Washington and London: Smithsonian Institution Press. 364 p.

HOGE, AR. and ROMANO HOGE, SARWL., 1978-79. Sinopse das serpentes peçonhentas do Brasil. 2 ed. Mem. Inst. Butantan, vol. 42-43, p. 373-499.

MARQUES, OAV., 1998. Composição faunística, história natural e ecologia de serpentes da Mata Atlântica, na região da Estação Ecológica Juréia-Itatins, São Paulo, SP. São Paulo: Instituto de Biociências, USP. 135 p. [Tese de Doutorado].

MARQUES, OAV., ETEROVIC, A. and SAZIMA, I., 2001. Serpentes da Mata Atlântica. Guia ilustrado para a Serra do Mar. Ribeirão Preto, SP: Holos Editora Ltda. 184 p.

MARTINS, M. and OLIVEIRA, ME., 1998. Natural history of snakes in forests of the Manaus Region, central Amazônia, Brazil. Herpetol. Nat. Hist., vol. 6, no. 2, p. 78-150.

MARQUES, OAV. and SAZIMA, I., 2004. História natural dos répteis da Estação Ecológica Juréia-Itatins. In Marques, AV. and Duleba, W. (Eds.). Estação Ecológica Juréia-Itatins. Ambiente físico, flora e fauna. Ribeirão Preto, SP: Holos Editora Ltda. p. $257-277$

PETERS, JA. and OREJAS MIRANDA, B., 1970. Catalogue of the neotropical Squamata. Part I: Snakes. Bull. U.S. Nat. Mus. vol. 297, p. 1-347.

PONTES, JAL., 2005. A comunidade de serpentes do Parque Natural Municipal da Serra do Mendanha, Rio de Janeiro, RJ: composição, riqueza e diversidade em áreas com diferentes graus de conservação. Rio de Janeiro: Departamento de Ecologia, Instituto de Biologia Roberto Alcântara Gomes, Universidade do Estado do Rio de Janeiro. 188 p. [Unpublished M.Sc. Dissertation].

PREFEITURA DA CIDADE DO RIO DE JANEIRO, 2000. Mapeamento e caracterização do uso das terras e cobertura vegetal no Município do Rio de Janeiro entre os anos de 1984 e 1999. Rio de Janeiro: Secretaria Municipal de Meio Ambiente. 75 p.

ROCHA, CFD., 1998. Composição e organização da comunidade de répteis da área de Mata Atlântica da região de Linhares, Espírito Santo. In: Anais do VIII Seminário regional de Ecologia. Programa de Pós-Graduação em Ecologia e Recursos Naturais. São Carlos, SP: UFSCar. vol. 8, p. 869-881.

ROCHA, CFD., LACERDA, P., SARMENTO, A. and MARQUES, AM., 2000. Introduction to the snake fauna of an area of Atlantic Rainforest in Southeastern Brazil (Casimiro de Abreu, RJ). In: Anais do Simpósio de ecossistemas brasileiros: conservação. São Paulo: ACIESP. 109, vol. 3, p. 139-146.

ROCHA, CFD., BERGALLO, HG., ALVES, MAS. and SLUYS, MV., 2003. A biodiversidade nos grandes remanescentes florestais do Estado do Rio de Janeiro e nas restingas da Mata Atlântica. São Carlos: RiMa Editora. 146 p.

ROCHA, CFD. and VAN SLUYS, M., 2006. New records of reptiles from Ilha Grande Island in Rio de Janeiro State, Brazil. Herpetol. Rev., vol. 37, no. 1, p. 112-114.

SAWAYA, RJ., 2003. História natural e ecologia das serpentes de Cerrado da região de Itirapina, SP. Campinas: Instituto de 
Pontes, JAL. et al.

Biologia, Universidade Estadual de Campinas. 145 p. [Tese de Doutorado].

SAZIMA, I. and HADDAD, CFB., 1992. Répteis da Serra do Japi: notas sobre história natural. In Morellato, LPC. (Ed.). História Natural da Serra do Japi. Ecologia e preservação de uma área florestal no Sudeste do Brasil. Campinas: Editora da UNICAMP/FAPESP. p. 212-213.

SECRETARIA ESTADUAL DE MEIO AMBIENTE E DESENVOLVIMENTO SUSTENTÁVEL DO RIO DE JANEIRO - SEMADS, 2001. Atlas das Unidades de Conservação da natureza do Estado do Rio de Janeiro. São Paulo: Metavídeo SP Produção e Comunicação Ltda. 48 p.
STRÜSSMANN, C., 1992. Serpentes do Pantanal de Poconé, Mato Grosso: composição faunística, história natural e ecologia comparada. Campinas: Instituto de Biologia, Universidade Estadual de Campinas, 126 p. [Dissertação de Mestrado em Ciências Biológicas]

VANZOLINI, PE., RAMOS COSTA, AM. and VITT, LJ., 1980. Répteis das Caatingas. Rio de Janeiro: Academia Brasileira de Ciências. $161 \mathrm{p}$.

ZUG, GR., VITT, LJ. and CALDWELL, JP., 2001. Herpetology. An introductory biology of amphibians and reptiles. California: Academic Press. 630 p. 


\section{Appendix 1}

Voucher specimens of the snake species recorded in the Atlantic Rainforest of Serra do Mendanha, Rio de Janeiro, Brazil, during the present study. Specimens were deposited in the Herpetological Collection of the Vertebrate Department of the Museu Nacional, Rio de Janeiro (MNRJ). We include for most specimens information on size (in mm), sex, mass (in g), the habitat and microhabitat in the Forest where the snake was found, altitude and the geographic coordinates.

\section{Serpentes}

\section{BOIDAE}

Boa constrictor Linnaeus, 1758. MNRJ 13177 Bica do Padre (Secondary forest, $60 \mathrm{~m}$ a.s.1.); 21 June 2004, 7:15 PM; J.A.L. Pontes and R.C. Pontes; juvenile male (686 mm TTL; $606 \mathrm{~mm} \mathrm{SVL} ; 132 \mathrm{~g})$, margin of the Guandu do Sena road (22 $2^{\circ} 0^{\prime} 10.9^{\prime \prime} \mathrm{S}$ and $43^{\circ} 30^{\prime} 12.1$ ' W).

\section{COLUBRIDAE}

Chironius bicarinatus (Wied, 1820). MNRJ 10976 - Trilha da Jararacuçu (Secondary forest, $80 \mathrm{~m}$ a.s.1.); 03 November 2002, 12:30 PM; J.A.L. Pontes and J.P. Figueiredo; adult female (1091 mm TTL; $837 \mathrm{~mm} \mathrm{SVL} ; 120 \mathrm{~g}$ ), on ground (22 $52^{\prime} 05.3^{\prime \prime} \mathrm{S}$ and $43^{\circ} 29^{\prime} 97.8^{\prime \prime} \mathrm{W}$ ).

Chironius exoletus (Linnaeus, 1758). MNRJ 10976 - Projeto SEMEAR property (Secondary forest, $36 \mathrm{~m}$ a.s.1.); 2003; J.A.L. Pontes and J.P. Figueiredo; adult female (725 mm TTL; $469 \mathrm{~mm}$ SVL; $16 \mathrm{~g}$ ), on ground (22 50' 17.3" S and 43 29' 59.1” W). MNRJ 10949 - Projeto SEMEAR property (Secondary forest, $36 \mathrm{~m}$ a.s.1.); 2003; J.A.L. Pontes and J.P. Figueiredo; adult female $(650 \mathrm{~mm}$ TTL; $394 \mathrm{~mm} \mathrm{SVL} ; 13 \mathrm{~g}$ ), on ground

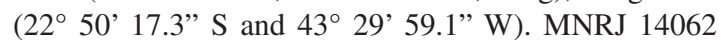
- margin of the Guandu do Sena road (Anthropic area, 26 m a.s.1.); 18 October 2005, 09:30 AM; J.A.L. Pontes; adult male (486 mm TTL; $732 \mathrm{~mm} \mathrm{SVL} ; 85 \mathrm{~g})$, moving on ground ( $22^{\circ} 50^{\prime} 25.0^{\prime \prime} \mathrm{S}$ and $\left.43^{\circ} 30^{\prime} 02.0^{\prime \prime} \mathrm{W}\right)$.

Chironius fuscus (Linnaeus, 1758). MNRJ 10960 margin of the Fundão river, in shrub (Secondary forest, 75 m a.s.1.); 24 May 2002, 11:00 AM; J.A.L. Pontes and J.P. Figueiredo; juvenile male (522 mm TTL; $360 \mathrm{~mm}$ SVL; $20 \mathrm{~g})$, moving on ground $\left(22^{\circ} 50^{\prime} 11.2^{\prime \prime} \mathrm{S}\right.$ and $43^{\circ}$ 29' 93.2” W). MNRJ 10959 - Área de Convivência do Parque 1 (Secondary forest, $75 \mathrm{~m}$ a.s.1.); 27 July 2002, 4:30 PM; J.A.L. Pontes and J.P. Figueiredo; adult female (640 mm TTL; $418 \mathrm{~mm} \mathrm{SVL;} 40 \mathrm{~g}$ ), on ground (22 $2^{\circ}$ ' 10.3" S and 43 ${ }^{\circ} 29^{\prime}$ 93.8” W). MNRJ 10958 margin of the Fundão river (Secondary forest, $78 \mathrm{~m}$ a.s.1.); 03 November 2002, 4:30 PM; J.A.L. Pontes and J.P. Figueiredo; adult male (1395 mm TTL; $950 \mathrm{~mm}$ SVL; $250 \mathrm{~g}$ ), on rocks ( $22^{\circ} 50^{\prime} 10.4^{\prime \prime} \mathrm{S}$ and $\left.43^{\circ} 29^{\prime} 87.0^{\prime \prime} \mathrm{W}\right)$. MNRJ 10954 - margin of the Fundão river (Secondary forest, $80 \mathrm{~m}$ a.s.1.); 02 March 2003, 12:45 PM; J.A.L. Pontes and J.P. Figueiredo; adult male (1025 mm TTL; $810 \mathrm{~mm} \mathrm{SVL} ; 175 \mathrm{~g}$ ), moving on rocks, body temperature $28.8^{\circ} \mathrm{C}\left(22^{\circ} 50^{\prime} 07.4^{\prime \prime} \mathrm{S}\right.$ and $\left.43^{\circ} 29^{\prime} 82.8^{\prime \prime} \mathrm{W}\right)$. MNRJ 13109 - margin of the Guandu do Sena road (Anthropic area, 26 m a.s.1.); 16 April 2005, 12:45 PM; J.A.L. Pontes and R.C. Pontes; adult male (1231 mm TTL; $789 \mathrm{~mm}$ SVL; $188 \mathrm{~g})$, moving on ground $\left(22^{\circ} 50^{\prime} 37.5^{\prime \prime} \mathrm{S}\right.$ and 43 29' 97.7' W)

Chironius laevicollis (Wied, 1824). MNRJ 10968 - Bica do Padre (Anthropic area, 63 m a.s.1.); 10 February 2004, 12:45 PM; J.A.L. Pontes and R.C. Pontes; adult male (1660 mm TTL; $1135 \mathrm{~mm} \mathrm{SVL}$; $650 \mathrm{~g})$, on tree, $3 \mathrm{~m}$ above ground $\left(22^{\circ} 50^{\prime} 06.4^{\prime \prime} \mathrm{S}\right.$ and $43^{\circ} 30^{\prime} 03.6$ " W). MNRJ 12505 - playground (Secondary forest, $72 \mathrm{~m}$ a.s.1.); 09 August 2004, 10:00 AM; J.A.L. Pontes and R.C. Pontes; juvenile female ( $378 \mathrm{~mm}$ TTL; $254 \mathrm{~mm} \mathrm{SVL}$; $9 \mathrm{~g})$, on ground (22 $50^{\prime} 11.4^{\prime \prime} \mathrm{S}$ and $43^{\circ} 29^{\prime}$ 92.4" W). MNRJ 13178 - Guandu do Sena road (Anthropic area, $26 \mathrm{~m}$ a.s.1.); 11 June 2005, 10:00 AM; J.A.L. Pontes and R.C. Pontes; juvenile female ( $427 \mathrm{~mm}$ TTL; $290 \mathrm{~mm} \mathrm{SVL} ; 10 \mathrm{~g})$, on ground (22 $50^{\prime} 37.5^{\prime \prime} \mathrm{S}$ and $43^{\circ} 29^{\prime}$ ' $97.7^{\prime \prime} \mathrm{W}$ ).

Echinanthera cephalostriata Di Bernardo, 1996. MNRJ 10978 - Trilha da Jararacuçu (Forest little disturbed, 448 m a.s.l.); 22 April 2002, 2:45 PM; J.A.L. Pontes and J.P. Figueiredo; adult female (651 mm TTL; $420 \mathrm{~mm} \mathrm{SVL} ; 50 \mathrm{~g}$ ), basking on leaf litter, body temperature $28^{\circ} \mathrm{C}\left(22^{\circ} 49^{\prime} 57.2^{\prime \prime} \mathrm{S}\right.$ and $\left.43^{\circ} 30^{\prime} 16.1^{\prime \prime} \mathrm{W}\right)$. MNRJ 10979 - draining trough on the playground (Secondary forest, $72 \mathrm{~m}$ a.s.1.); 31 May 2003, 7:10 AM; J.A.L. Pontes and J.P. Figueiredo; juvenile female (212 mm TTL; $149.5 \mathrm{~mm} \mathrm{SVL} ; 5 \mathrm{~g}$ ), moving on ground (22 $2^{\circ}$ ' $11.4^{\prime \prime} \mathrm{S}$ and $43^{\circ} 29^{\prime}$ '92.4" W).

Elapomorphus quinquelineatus (Raddi, 1820). MNRJ 14086 - Caixinha road (Anthropic area, $30 \mathrm{~m}$ a.s.1.); 02 December 2005, 10:00 AM; J.A.L. Pontes; juvenile female ( $236 \mathrm{~mm}$ TTL; $211 \mathrm{~mm} \mathrm{SVL} 3 \mathrm{~g}$ ), moving on ground (22 $50^{\circ} 17.3^{\prime \prime} \mathrm{S}$ and $\left.43^{\circ} 29^{\prime} 59.1^{\prime \prime} \mathrm{W}\right)$.

Helicops carinicaudus (Wied, 1825). MNRJ 10973 - Guandu do Sena road (Anthropic area, $30 \mathrm{~m}$ a.s.1.); 31 October 2003, 6:00 PM; J.A.L. Pontes and J.P. Figueiredo; adult female (1165 mm TTL; $990 \mathrm{~mm}$ SVL; $750 \mathrm{~g}$ ), moving on ground (22 $50^{\prime} 28.1^{\prime \prime} \mathrm{S}$ and $43^{\circ} 29^{\prime} 49.2^{\prime \prime}$ W). MNRJ 14082 - Guandu do Sena road (Anthropic area, $26 \mathrm{~m}$ a.s.1.); 05 January 2006, 9:30 AM; J.A.L. Pontes and R.C. Pontes; adult male (657 mm TTL; $485 \mathrm{~mm} \mathrm{SVL} ; 82 \mathrm{~g})$, moving on ground $\left(22^{\circ} 50^{\prime} 25.0^{\prime \prime} \mathrm{S}\right.$ and $43^{\circ} 30$ ' $02.0^{\prime \prime} \mathrm{W}$ ).

Leptophis ahaetulla (Linnaeus, 1758). MNRJ 10967 - near the showers (Secondary forest, $68 \mathrm{~m}$ a.s.1.); 19 July 2003, 7:10 AM; J.A.L. Pontes and J.P. Figueiredo; adult female (1172 mm TTL; $720 \mathrm{~mm} \mathrm{SVL;}$ $70 \mathrm{~g}$ ), on a tree branch $3 \mathrm{~m}$ above ground (22 $50^{\prime} 13.8^{\prime \prime} \mathrm{S}$ and 43 29' 95.4" W). MNRJ 10966 - Caixinha road (Secondary forest, $61 \mathrm{~m}$ a.s.1.); 18 April 2004, 
2:00 PM; J.A.L. Pontes and R.C. Pontes; adult female (824 mm TTL; $498 \mathrm{~mm} \mathrm{SVL} ; 22 \mathrm{~g}$ ), moving on ground (22 50' $22.9^{\circ}$ ' S and $43^{\circ} 29^{\prime} 91.3^{\prime \prime} \mathrm{W}$ ).

Liophis miliaris (Linnaeus, 1758). MNRJ 10953 circular trail, margin of the Fundão river (Secondary forest, 76 m a.s.1.); 31 August 2002, 2:00 PM; J.A.L. Pontes and J.P. Figueiredo; adult male (1060 mm TTL; $900 \mathrm{~mm}$ SVL; $420 \mathrm{~g}$ ), moving on ground (22 $50^{\prime}$ 07.4" $\mathrm{S}$ and $43^{\circ} 29^{\prime} 82.8^{\prime}$ W). MNRJ 10955 - rural property, near the Guandu do Sena road (Anthropic area, $18 \mathrm{~m}$ a.s.l.); 14 March 2003, 12:00 PM; J.A.L. Pontes and J.P. Figueiredo; adult female $(639.2 \mathrm{~mm}$ TTL; $611 \mathrm{~mm}$ SVL; $100 \mathrm{~g}$ ), moving in swamp (22 50'48.1" $\mathrm{S}$ and $43^{\circ} 29^{\prime} 17.3$ " W). MNRJ 10956 - Projeto SEMEAR property (Anthropic area, $36 \mathrm{~m}$ a.s.l.); 2003; J.A.L. Pontes and J.P. Figueiredo; adult female (708 mm TTL; $585 \mathrm{~mm}$ SVL; $94 \mathrm{~g})$, moving on ground ( $22^{\circ} 50^{\prime} 17.3^{\prime \prime} \mathrm{S}$ and $43^{\circ} 29^{\prime}$ 59.1' W). MNRJ 10975 - Caixinha road, near the entrance (Secondary forest, $62 \mathrm{~m}$ a.s.l.); 27 November 2003, 4:50 PM; J.A.L. Pontes and J.P. Figueiredo; adult female (817 mm TTL; $675 \mathrm{~mm}$ SVL; $162 \mathrm{~g}$ ), moving on ground ( $22^{\circ} 50^{\prime} 22.9^{\prime \prime} \mathrm{S}$ and $43^{\circ} 29^{\prime}$ 91.3" W). MNRJ 12507 - margin of the Guandu do Sena road (Anthropic area, $26 \mathrm{~m}$ a.s.l.); 04 December 2004, 11:15 AM; J.A.L. Pontes and R.C. Pontes; adult female (628 mm TTL; $508 \mathrm{~mm} \mathrm{SVL} ; 120 \mathrm{~g}$ ), moving on ground ( $22^{\circ} 50^{\prime} 37.5^{\prime \prime} \mathrm{S}$ and $43^{\circ} 29^{\prime}$ 97.7' W). MNRJ 13110 - rural property, Guandu do Sena road (Anthropic area, 30 m a.s.1.); 21 April 2005, 12:30 PM; J.A.L. Pontes and R.C. Pontes; adult female (801 mm TTL; $715 \mathrm{~mm}$ SVL; $198 \mathrm{~g})$, moving on ground $\left(22^{\circ} 51^{\prime} 15.0^{\prime \prime} \mathrm{S}\right.$ and $\left.43^{\circ} 28^{\prime} 45.0^{\prime \prime} \mathrm{W}\right)$. MNRJ 14083 - margin of the Guandu do Sena road (Anthropic area, $38 \mathrm{~m}$ a.s.l.); 25 September 2005, 10:00 AM; J.A.L. Pontes and R.C. Pontes; adult female (829 mm TTL; $690 \mathrm{~mm} \mathrm{SVL} ; 134 \mathrm{~g}$ ), moving on ground ( $22^{\circ} 50^{\prime} 37.5^{\prime \prime} \mathrm{S}$ and $\left.43^{\circ} 29^{\prime} 22.6^{\prime \prime} \mathrm{W}\right)$. MNRJ 14084 - margin of the Guandu do Sena road (Anthropic area, 26 m a.s.1.); 25 December 2005, 11:00 AM; J.A.L. Pontes and R.C. Pontes; adult female ( $826 \mathrm{~mm}$ TTL; $672 \mathrm{~mm} \mathrm{SVL} ; 147 \mathrm{~g}$ ), moving on ground ( $22^{\circ} 50^{\prime} 25.0^{\prime \prime} \mathrm{S}$ and $43^{\circ} 30^{\prime} 02.0^{\prime \prime} \mathrm{W}$ ).

Liophis poecilogyrus (Wied, 1835). MNRJ 10950 Projeto SEMEAR property (Anthropic area, $36 \mathrm{~m}$ a.s.1.); 2003; J.A.L. Pontes and J.P. Figueiredo; adult female (792 mm TTL; $650 \mathrm{~mm} \mathrm{SVL} ; 80 \mathrm{~g}$ ), moving on ground

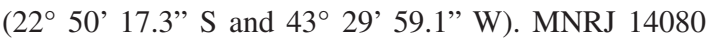
- margin of the Guandu do Sena road (Anthropic area, 36 m a.s.1.); 04 January 2006, 2:00 PM; J.A.L. Pontes and R.C. Pontes; adult male $(584 \mathrm{~mm}$ TTL; $464 \mathrm{~mm}$ SVL; $52 \mathrm{~g})$, moving on ground $\left(22^{\circ} 50\right.$ ' $17.0^{\prime \prime} \mathrm{S}$ and $43^{\circ} 29$ ' 16.1" W).

Oxyrhopus petola (Linnaeus, 1758). MNRJ 10943 - rural property, Bica do Padre (Anthropic area, 65 m a.s.1.); 08 April 2003, 12:30 AM; J.A.L. Pontes and J.P. Figueiredo; adult female (843 mm TTL; $675 \mathrm{~mm}$ SVL; $80 \mathrm{~g})$, moving on ground (22 $2^{\circ} 50^{\prime} 10.9^{\prime \prime} \mathrm{S}$ and $43^{\circ} 30^{\prime} 12.1$ ' W). MNRJ 10950 - Projeto SEMEAR property (Anthropic area, $36 \mathrm{~m}$ a.s.1.); 2003; J.A.L. Pontes and
J.P. Figueiredo; female juvenile (310 mm TTL; $242 \mathrm{~mm}$ SVL; $7 \mathrm{~g}$ ), hidden under vegetation (22 $52^{\prime} 17.3^{\prime \prime} \mathrm{S}$ and $43^{\circ} 29^{\prime} 59.1$ " W). MNRJ 13179 - margin of Guandu do Sena road (Anthropic area, 36 m a.s.1.); 27 June 2005, 9:00 PM; J.A.L. Pontes and R.C. Pontes; adult female (867 mm TTL; $700 \mathrm{~mm} \mathrm{SVL;} 76 \mathrm{~g}$ ), moving on ground $\left(22^{\circ} 50^{\prime} 30.0^{\prime \prime} \mathrm{S}\right.$ and $\left.43^{\circ} 29^{\prime} 22.5^{\prime \prime} \mathrm{W}\right)$.

Philodryas olfersii (Lichtenstein, 1823). MNRJ 12506 - rural property, Bica do Padre (Anthropic area, 65 m a.s.1.); 29 September 2004, 12:30 PM; J.A.L. Pontes and R.C. Pontes; female adult (979 mm TTL; $705 \mathrm{~mm}$ SVL; $110 \mathrm{~g})$, on wooden structure $\left(22^{\circ} 50^{\prime} 48.1^{\prime \prime} \mathrm{S}\right.$ and $\left.43^{\circ} 29^{\prime} 17.3^{\prime \prime} \mathrm{W}\right)$. MNRJ 14063 - margin of the Guandu do Sena road (Anthropic area, $26 \mathrm{~m}$ a.s.1.); 25 November 2005, 2:00 PM; J.A.L. Pontes; adult female (305 mm TTL; $913 \mathrm{~mm} \mathrm{SVL} ; 150 \mathrm{~g}$ ), moving on ground (22 $50^{\circ} 17.0^{\prime \prime} \mathrm{S}$ and $\left.43^{\circ} 29^{\prime} 16.0^{\prime \prime} \mathrm{W}\right)$.

Spilotes pullatus (Linnaeus, 1758). MNRJ 10977 margin of Caixinha road (Secondary forest, $62 \mathrm{~m}$ a.s.1.); 22 August 2002, 1:15 PM; J.A.L. Pontes and J.P. Figueiredo; adult female (1900 mm TTL; $1367 \mathrm{~mm}$ SVL; $950 \mathrm{~g})$, moving on ground, body temperature $28.6^{\circ} \mathrm{C}\left(22^{\circ} 50^{\prime} 22.9^{\prime \prime} \mathrm{S}\right.$ and $\left.43^{\circ} 29^{\prime} 91.3^{\prime \prime} \mathrm{W}\right)$. MNRJ 10983 - rural property, Bica do Padre (Secondary forest, 62 m a.s.1.); 22 April 2003, 12:00 PM; J.A.L. Pontes and J.P. Figueiredo; adult male (1928 mm TTL; 1396 mm SVL; $1225 \mathrm{~g}$ ), attempting to enter a poultry-gard (22 $2^{\circ}$ ' 10.9' $\mathrm{S}$ and $\left.43^{\circ} 30^{\prime} 12.1^{\prime \prime} \mathrm{W}\right)$.

Thamnodynastes hypoconia (Cope, 1860). MNRJ 10952 - near the park's head office (Secondary forest, 70 m a.s.1.); 01 February 2003, 9:30 AM; J.A.L. Pontes and J.P. Figueiredo; adult female (472 mm TTL; $354 \mathrm{~mm}$ SVL; $16 \mathrm{~g})$, moving on ground $\left(22^{\circ} 50^{\prime} 08.3^{\prime \prime} \mathrm{S}\right.$ and 4329'92.8”'W). MNRJ 10963 -born in box (Head office, 70 m a.s.1.); 22 September 2002, 9:30 AM; J.A.L. Pontes and J.P. Figueiredo; juvenile (201 mm TTL; $149 \mathrm{~mm}$

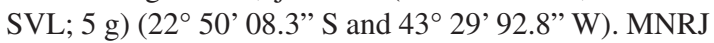
13911 - margin of the Fundão river (Secondary forest, 75 m a.s.1.); 08 September 2005, 1:40 PM; J.A.L. Pontes (178.2 mm TTL; $132 \mathrm{~mm} \mathrm{SVL} ; 2 \mathrm{~g}$ ) (22 $2^{\circ} 50^{\prime} 11.2^{\prime \prime} \mathrm{S}$ and 43 20'93.2" W). MNRJ 14081 - margin of the Guandu do Sena road (Anthropic area, $36 \mathrm{~m}$ a.s.1.); 14 December 2005, 11:00 AM; J.A.L. Pontes and R.C. Pontes; adult male (774 mm TTL; $586 \mathrm{~mm} \mathrm{SVL} ; 57 \mathrm{~g}$ ), moving on ground ( $22^{\circ} 50^{\prime} 17.0^{\prime} \mathrm{S}$ and $\left.43^{\circ} 29^{\prime} 16.1^{\prime} \mathrm{W}\right)$.

Uromacerina ricardinii (Peracca, 1897). MNRJ 10948 - near park's natural pool (Secondary forest, 70 m a.s.1.); 22 May 2002, 1:00 PM; J.A.L. Pontes and J.P. Figueiredo; juvenile female (283 mm TTL; $162.5 \mathrm{~mm} \mathrm{SVL} ; 5 \mathrm{~g}$ ), moving on ground, after rain (22 50' $12.3^{\circ}$ ' S and 43 29' 93.5' W).

Xenodon neuwiedii Günther, 1863. MNRJ 10962 - near park entrance (Secondary forest, $70 \mathrm{~m}$ a.s.1.); 16 July 2002, 12:00 PM; J.A.L. Pontes and J.P. Figueiredo; adult female (835 mm TTL; $714 \mathrm{~mm}$ SVL; $130 \mathrm{~g})$, moving on ground (22 $2^{\circ} 50^{\prime} 08.0^{\prime \prime} \mathrm{S}$ and $43^{\circ} 29^{\prime}$ 92.8" W). MNRJ 10982 - Bica do Padre (Secondary forest, $68 \mathrm{~m}$ a.s.1.); 16 July 2002, 12:00 PM; 
J.A.L. Pontes and J.P. Figueiredo; adult female $(771 \mathrm{~mm}$ TTL; $649 \mathrm{~mm} \mathrm{SVL;} 120 \mathrm{~g}$ ), moving on ground (22 $50^{\prime} 10.9^{\prime \prime} \mathrm{S}$ and $43^{\circ} 30^{\prime} 12.1$ ' W). MNRJ 10974 Area of the Projeto SEMEAR (Anthropic area, $36 \mathrm{~m}$ a.s.1.); 2003; J.A.L. Pontes and J.P. Figueiredo; adult female (825 mm TTL; $710 \mathrm{~mm}$ SVL; 101g), hidden under vegetation $\left(22^{\circ} 50^{\prime} 17.3^{\prime \prime} \mathrm{S}\right.$ and $\left.43^{\circ} 29^{\prime} 59.1^{\prime \prime} \mathrm{W}\right)$. MNRJ 10971 - playground (Secondary forest, $72 \mathrm{~m}$ a.s.1.); 24 December 2003, 7:30 AM; J.A.L. Pontes and J.P. Figueiredo; juvenile female (208 mm TTL; $171 \mathrm{~mm}$ SVL; $3 \mathrm{~g}$ ), moving on ground (22 50 ' 11.4 " $\mathrm{S}$ and 4329' 92.4”W). MNRJ 13180 - margin of Caixinha road (Secondary forest, $36 \mathrm{~m}$ a.s.1.); 02 July 2005, 1:15 PM; J.A.L. Pontes and R.C. Pontes; adult female $(802 \mathrm{~mm}$ TTL; $678 \mathrm{~mm} \mathrm{SVL} ; 130 \mathrm{~g}$ ), moving on ground, attempting to prey on a toad, Bufo ornatus (22 $50^{\prime} 17.3^{\prime \prime} \mathrm{S}$ and $43^{\circ} 29^{\prime} 59.1$ ' W).

\section{ELAPIDAE}

Micrurus corallinus (Merrem, 1820). MNRJ 10971 - park entrance (Secondary forest, $70 \mathrm{~m}$ a.s.l.); 26 March 2003, 10:15 AM; J.A.L. Pontes and J.P. Figueiredo; juvenile male (286 mm TTL; $255 \mathrm{~mm}$ SVL; $7 \mathrm{~g})$, moving on ground (22 $52^{\prime} 16.5^{\prime \prime} \mathrm{S}$ and $43^{\circ} 29^{\prime}$ 93.9" W). MNRJ 10964 - trail of Bica do Padre (Secondary forest, $60 \mathrm{~m}$ ); 28 April 2003, 11:00 AM; J.A.L. Pontes and J.P. Figueiredo; juvenile female (239 mm TTL; $210 \mathrm{~mm} \mathrm{SVL;} 6 \mathrm{~g}$ ), moving on ground (22 50' 10.9” S and 43 30' 12.1" W). MNRJ 10969 Projeto SEMEAR property (Anthropic area, $36 \mathrm{~m}$ a.s.1.); 2003; J.A.L. Pontes and J.P. Figueiredo; adult male (459 mm TTL; $395 \mathrm{~mm} \mathrm{SVL} ; 11 \mathrm{~g}$ ), hidden under vegetation (22 $50^{\prime} 17.3$ ' $\mathrm{S}$ and $\left.43^{\circ} 29^{\prime} 59.1^{\prime \prime} \mathrm{W}\right)$. MNRJ 10947 - parking lot (Secondary forest, $70 \mathrm{~m}$ a.s.l.); 03 April 2004, 12:00 PM; J.A.L. Pontes; juve- nile (186.6 mm TTL; $166 \mathrm{~mm} \mathrm{SVL;} 2 \mathrm{~g}$ ), moving on

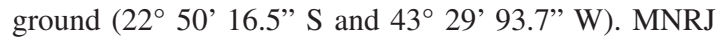
13910 - rural property, Furnas road (Secondary forest, 225 m a.s.1.); 20 August 2005, 3:00 PM; J.A.L. Pontes (622 mm TTL; $568 \mathrm{~mm} \mathrm{SVL;} \mathrm{36g),} \mathrm{moving} \mathrm{on} \mathrm{ground}$ $\left(22^{\circ} 50^{\prime} 00^{\prime \prime} \mathrm{S}\right.$ and $43^{\circ} 31^{\prime}$ 52.5" W). MNRJ $13912-$ Projeto SEMEAR property (Anthropic area, $36 \mathrm{~m}$ a.s.1.); 29 September 2005, 3:00 PM; J.A.L. Pontes; adult male (720 mm TTL; $624 \mathrm{~mm} \mathrm{SVL;} 70 \mathrm{~g}$ ), moving on ground (22 $50^{\prime} 17.3^{\prime \prime} \mathrm{S}$ and $\left.43^{\circ} 29^{\prime} 59.1^{\prime \prime} \mathrm{W}\right)$. MNRJ 14085 rural property, Bica do Padre (Secondary forest, $63 \mathrm{~m}$ ); 04 January 2006, 15:00 h; J.A.L. Pontes and R.C. Pontes; adult female ( $840 \mathrm{~mm}$ TTL; $767 \mathrm{~mm} \mathrm{SVL} ; 114 \mathrm{~g}$ ), moving on ground (22 $50^{\prime} 10.9^{\prime}$ S and $\left.43^{\circ} 30^{\prime} 12.1^{\prime \prime} \mathrm{W}\right)$.

\section{VIPERIDAE}

Bothrpops jararaca (Wied, 1824). MNRJ 10965 rural property, Bica do Padre (Secondary forest, $63 \mathrm{~m}$ a.s.1.); 11 June 2003, 11:00 AM; J.A.L. Pontes and J.P. Figueiredo; adult male (680 mm TTL; $589 \mathrm{~mm} \mathrm{SVL} ; 50 \mathrm{~g})$, resting on ground (22 $50^{\prime} 10.9^{\prime \prime} \mathrm{S}$ and $\left.43^{\circ} 30^{\prime} 12.1^{\prime \prime} \mathrm{W}\right)$. MNRJ 10957 - Projeto SEMEAR property (Anthropic area, $36 \mathrm{~m}$ a.s.1.); 2003; J.A.L. Pontes and J.P. Figueiredo; adult male (1100 mm TTL; $960 \mathrm{~mm} \mathrm{SVL;} 189 \mathrm{~g}$ ), hidden under vegetation (22 $50^{\circ} 17.3^{\prime \prime} \mathrm{S}$ and $43^{\circ} 29^{\prime} 59.1^{\prime \prime} \mathrm{W}$ ). MNRJ 13108 - near the area of the Projeto SEMEAR (Anthropic area, $36 \mathrm{~m}$ a.s.l.); 17 April 2005, 10:10 AM; J.A.L. Pontes and R.C. Pontes; female adult $(972 \mathrm{~mm}$ TTL; $831 \mathrm{~mm} \mathrm{SVL} ; 107 \mathrm{~g}$ ), basking on ground near a residence (22 $50^{\circ} 17.3^{\prime \prime} \mathrm{S}$ and $\left.43^{\circ} 29^{\prime} 59.1^{\prime \prime} \mathrm{W}\right)$.

Bothrops jararacussu Lacerda, 1884. MNRJ 10972 - Bica do Padre (Secondary forest, $72 \mathrm{~m}$ a.s.1.); 19 October 2003, 1:15 PM; J.A.L. Pontes and J.P. Figueiredo; adult female (1426 mm TTL; $1280 \mathrm{~mm}$ SVL; $680 \mathrm{~g}$ ), resting on ground (22 $52^{\prime} 02.2^{\prime \prime} \mathrm{S}$ and $43^{\circ} 30^{\prime} 15.1$ ' W). 